\title{
Telephone: The Old Technology That Is Never Old
}

\author{
http://dx.doi.org/10.3991/ijet.v7i3.2132 \\ Olubunmi Philip Aborisade \\ College of New Rochelle, New York, USA.
}

\begin{abstract}
Telephone technology is a technology that stands the test of time. Since it was invented in 1876 by Alexander Graham Belle, it has remained the technology of all time. This article reports the major findings of a recent research, 'How Technology Transforms Citizen Journalism Business in Nigeria'. According to the research, Telephone technology has over the years emerged a major tool with which ordinary citizens in Nigeria (without journalism and media background or affiliation) participate in the process of news gathering, reporting and distribution. Guided by the recent use of telephone around the world by ordinary citizens to report themselves during protests through different social media outlets-Facebook, Tweeter, Youtube, the article illuminates the evergreen nature of the telephone. The article therefore concluded that the telephone technology has survived the test of time. Instead of being obsolete, it blends with emerging communications technology to improve on its performance.
\end{abstract}

Index Terms-Citizen Journalism, Communication Technology, GSM Telephone, Social Media,

\section{INTRODUCTION}

When telephone technology was invented in 1876 by Alexander Graham Belle, many believed it was a technology that would soon be replaced by another technology. But decades after, the technology is still not obsolete. Rather, it continues to improve on its performance and blends with emerging communications technology. It remains relevant as it survives and blends with every emerging technology. The telephone that used to be stationary when it was invented is now mobile with the arrival of Global System for Mobile (GSM). The wired feature of the telephone is now wireless, while the bulky receivers that it was noted for have been made portable. The telephone has become a veritable communication tool of all time. It has become part and parcel of the communication culture. The following attests to the significance of telephone in every human creature:

"The telephone rings, it jingles our psyches, jangles our nerves. We are seduced and soothed, rattled and betrayed by it. Wherever it is-on the desk or street corner, the high seas or highway, in our bathrooms or briefcasesit has, for a machine, an allure like no other" [13].

To the sub Saharan Africans, telephone has come a long way in preserving its oral culture and it continues to preserve it. Telephone has indeed come to stay. This is in line with Ejiofor's assertion that telephone is a communication of the future [10]. Over the years, emerging communication technologies have proved this assertion right. Rather than becoming obsolete, emerging communica- tions technology continue to build on telephone technology, making it relevant as new communications technology emerge.

With the invention of the Internet, the use of telephone continues to grow as many Internet sites integrate the telephone technology to enhance their communicative tools. As we enter the era of social media, telephone continues to play a leading role in the use of social media as ordinary citizens find telephone very complementary to social media tools like Facebook, Twitter, Myspace YouTube, Linked and others which can easily be accessed on the mobile phone (texts, audio and video). The integration of audio tools to some social media software further enhances oral communication through social media.

The research on "how technology transforms journalism business through citizen-reporters in Nigeria” investigated how ordinary citizens in Nigeria without journalism background use GSM to report the news. While some call the new development participatory journalism, some call it citizen journalism, and others dub it we media or grassroots journalism [5]. However, contemporary studies on the impacts of technology on journalism identify a serious threat to the traditional roles of journalists from citizens without formal training in news reporting who contribute news items to the mainstream media [9]. With citizenreporting, any person could hypothetically be a journalist. This is in line with [11] observation that the Internet and other technologies have expanded the universe of those who can contribute information to public debate.

\section{Purpose OF THE STUdY}

This purpose of the study is to identify the most important technology advances in Nigeria citizen-reporting and how they transform the news delivery business in Nigeria. This was achieved by tapping into the lived experiences of Nigerian journalists (citizen-reporters and traditional journalists) and news audience to determine the impacts of technology on citizen newsmen and journalism business in the country. By so doing, the study is adding to the emerging body of literature on the impacts of technology on citizen journalism in relation to Nigeria. The study therefore, investigated the impacts of technology on citizenreporters and news business in Nigeria to determine how emerging technologies and media modalities in digital technologies impact the journalism practice and business in Nigeria.

By presenting the Nigerian perspective on the impacts of technology on citizen reporting and journalism business, the study is added a fresh angle to the body of knowledge on the topic, thus, building on the foundation laid by earlier seminal work on the topic in relation to the Western media. 
Against the background of media repression in Nigeria, the study argued that technology is revolutionizing journalism in Nigeria as it empowers the Nigerian press in terms of expanded news sources, wider news coverage, and escape from government suppression of the news. The lived experiences of the interviewees for the study illuminate how technology transforms journalism practice and business in Nigeria.

With Internet and other media technologies, Nigerian citizen-reporters now have access to new sources of news, they can report Nigerian news from anywhere around the world, and above all, publish without any form of censorship by the Nigerian government. This is unlike the past when Nigerian government closed down media organizations and confiscated news publications with impunity to prevent the Nigerian public from knowing the truth about their government and country. These are the problems necessitating this study to determine how technology (through citizen journalism) is helping to resolve these problems.

\section{RESEARCH QUESTIONS}

The study was guided by the following research questions: (1) What are the main technologies used by citizenreporters in Nigeria and their impacts on the journalism business as a whole? (2) How does the new business model introduced by citizen-reporters transform the news delivery business in Nigeria? (3) What are the impacts of citizen-reporters on democracy, free speech, and the public sphere in Nigeria?

\section{THEORETICAL FOUNDATION}

The Adaptive Structuration Theory" [3] was adapted by the research to explain how the use of technology and media modalities in digital technologies transform news writing, reporting, and distribution in Nigeria. The theoretical framework established by Henry Jenkins, a key theorist of new media and media convergence also served as the basis for the study. Jenkins views the media from the perspective of users and participatory culture. His theory centers on the "transformation of media in early $21^{\text {st }}$ century from a system of mass communication, based on one-to-many message transmission and a structural separation between the producer and consumer of media, to one where both now constitute participants who interact with each other according to a new set of rules that none of us fully understands” [4] (p. 63).

The research further adds to the theoretical framework in this area of study by formulating a theory of the "techno-media Nigerian community". This model explains the emerging technological advancements which allow citizens without journalism training to take advantage of the new media platforms (or emerging media modalities in digital technologies) to gather and circulate Nigerian news. The "techno-media theory" argues that the use of emerging technology and media modalities in the digital technologies to gather, report and distribute Nigerian news has created a Nigerian news reporting community that takes advantage of emerging technology to do citizenreporting in support of Nigeria's political struggle, free speech, and to create a news public sphere akin to that of Jurgen Habermas [4].

\section{LITERATURE REVIEW}

The body of literature views the new development in journalism as inevitable, but cautions the traditional journalists to be prepared for a new era in journalism or be rendered irrelevant [5]. Gillmor [5] in this seminal work, demonstrates how individuals without journalism training can produce news using blogs, chat groups, e-mail, and many other news gathering, reporting, and distribution tools. The author challenges journalists, newsmakers (politicians, business executives, and celebrities), and marketers who promote them (PR flacks) to wake up to the realities of the new journalism and shift from 'control' to engagement. In particular, Gillmor challenges traditional journalists to be prepared to change and operate within the dynamics of the new era or be rendered irrelevant in the business of news gathering, reporting, and distribution.

While the literature review for the research unveils how citizen-reporting has emerged over years and its modus operandi, the research contributes to knowledge by taking a closer look at the tools employed by citizen-reporters to gather, report and distribute the news. In Nigeria which is the focus of the research and other countries where citizen-reporting is just developing, the research pinpointed the major tools of the trade and concluded that telephoneGSM has played a leading role in the process of news gathering, reporting and distribution. Thus, the telephone remains relevant in the business of news production by citizen-reporters.

\section{Methodology}

The research is a phenomenological, qualitative study that tapped into the lived experiences of Nigerian journalists, citizen-reporters, and their audiences to determine how technology impacts news delivery in the country. To investigate the impacts of technology on citizen news correspondents in Nigeria, this study used qualitative methods consisting of observations of Nigerian citizen media websites, Nigerian print media online editions, and interviews with Nigerian citizen and print journalists for an in-depth investigation of the topic.

Since there are different categories of print media in Nigeria, the study focused on the national daily newspapers, mostly Lagos-based (Lagos is the commercial nerve of Nigeria) English publications. These publications include The Guardian, Punch, Tribune, This Day, Vanguard, The Nation, Champion, Daily Independent, Compass, and Next. These daily newspapers have always been in the vanguard of the struggle for democracy, free speech, and good governance in Nigeria and they all have both print and online editions.

\section{A. Research Design}

The research design for this study is guided by Cooper and Schindler's [2] eight descriptors of research design:

[a] The degree to which the research question has been crystallized, [b] the method of data collection, [c] the power of the researcher to produce effect in the variables under study, [d] the purpose of the study, [e] the time dimension, [f] the topical scope-breadth and depth-of the study, [g] the research environment, and [h] the participants' perceptions of research activity. (p. 142) 
These descriptors enabled the researcher to put in place, a procedural outline for the study. As an exploratory study (qualitative), the research adopted a three-stage design interview with the population being studied (Nigerian citizen-reporters, print journalists, and their audience) and observation of some Nigerian citizen news websites and the online edition of some Nigerian news publications.

To effectively explore how technology creates citizenreporters and influences the news business in Nigeria, this study relied on an explanatory effect matrix and case dynamics matrix. The use of an explanatory effect matrix, according to Miles and Huberman [8], this allows the researcher to "know what is going on and how things are proceeding... to understand and explain coherently, why things occur as they do" (p. 90). The second element, a case dynamics matrix, "displays a set of forces for change and traces the consequential processes and outcomes" [8] (p. 148).

With explanatory effect matrix and case dynamics, this research did an in-depth study of how technology produces citizen-reporters in Nigeria. Explanatory effects matrix allowed the researcher to talk to users of an innovation (like citizen journalism), to know what an innovation is made up of and its effect. Case dynamics matrix allowed the researcher to answer the questions of how and why an innovation, such as citizen-reporting, induces change in the Nigerian journalism practice and business [8].

However, causal network was the least useful for the study. Since the study was designed to investigate, indepth, the lived experiences of the Nigerian print journalists and online news audience in relation to citizenreporters, the researcher believed the approach could not accommodate the avalanche of information that emerged in the course of the study. As Miles and Hubaman [8] said, this type of approach entails only "a display of the most important, independent, and dependent variables in a field of study" (p. 153). This study definitely went beyond that in the process of tapping into the lived experiences of the participants investigated for this study. The use of causal network would, therefore, be a misfit as it works better for quantitative study than qualitative study.

\section{B. Sample}

In line with voice of the customer research by [6] which supports 20-30 participants as capable of expressing $90 \%$ or more of the requirements for new products, the sample for the study was pegged to 30 participants (10 citizenreporters, 10 print journalists and 10 readers of Nigerian online news). Bock and Sergeant [1] also argued in favor of 30 or less participants in a qualitative study designed to generate a list of factors. Each of the participants for the study was interviewed for about one hour, during which each participants relayed their lived experiences with citizen-reporting.

\section{DATA COLLECTION}

The data collection for the study involved three categories of participants (with different sets of questions for each category): Nigerian citizen-reporters, print journalists, and online news audiences. The three sets of interviews with the three categories of participants addressed the previous questions, effectively providing copious insights into how technology transforms the journalism business through citizen-reporters in Nigeria.

Ten Nigerian citizen-journalism websites were reviewed to assess the activities of citizen-reporters in their news gathering, reporting, and distribution process. These websites were

- Nigerian Village Square: http://www.nigeriavillage square.com/

- Sahara Reporters: http://www.saharareporters.com

- Elendu Report: http://www.elendureports.com/

- Pointblank News: http://www.pointblanknews.com/

- Watchdog Reporter: http://www.watchdogreporters. com/

- Times of Nigeria: http://www.thetimesofnigeria.com/

- Sharpedgenews: http://www.sharpedgenews.com/ind ex.shtml

- iReports-ng.com: http://ireports-ng.com

- Xclusive Nigeria: http://www.xclusivenigeria.com/

- Jlero: http://www.jlero.org/

Ten websites of Nigerian news publications were reviewed for the presence of citizen-reporters in their news. These websites were

- The Guardian: http://www.ngrguardiannews.com/

- Punch: http://www.punchng.com/

- Tribune: http://www.tribune.com.ng/index.php

- Vanguard: http://www.vanguardngr.com/

- The Nation: http://www.thenationonlineng.net/web2/

- This Day: http://www.thisdayonline.com/

- Daily Independent: http://www.independentngonli ne.com/

- Champion Newspaper: http://www.champion.com.ng

- Compass: http://www.compassnewspaper.com/NG/

- Next: http://234next.com

Levine's [8] five principles for storage and retrievalformatting, cross-referral, indexing abstracting, and pagination were used to collate the data interviews and review of websites for easy analysis. With these principles, the field notes were organized in computer files and notebook with dates and names, connect information in one file to information in another file, code information for easy recognition, summarize field notes, and use paginationunique numbers and letters to locate information on field notes.

To implement Levine's [8] five principles, a word processor was used to organize the interviews and field notes to enhance the quality of the study and help coordinate the numerous data the researcher had to review so as to be able to come up with a robust qualitative study. Data from interviews, observations, and literature for the study, were also managed with a matrix display [8].

\section{FINDINGS OF THE RESEARCH}

One of the major findings of the research (How technology transforms the business of journalism though citizen reporters in Nigeria) is that, telephone (GSM technology) is one of the leading tools of citizen journalism in Nigeria. The study reveals that it is the backbone of citizen-journalism in Nigeria. Without the GSM technol- 
ogy, it would have been impossible for ordinary citizens in Nigeria to participate in the process of news gathering, reporting and distribution as they do today. Also, the research proves that the use of social media for networking in the country depends on the GSM as most citizens who cannot afford a computer access social media sites on their GSM.

The research reports that new technologies have further empowered the Nigerian citizens to speak out against bad policies of the government. This is unlike the past when the Nigerian government used to gag the press by shutting down media outlets illegally for carrying stories that are critical of the government. The research concluded that such practice is no longer possible because if the government shuts down media outlets in other to prevent them from criticizing the government, ordinary citizens (citizenreporters) will still report the news to the world using the Internet, Facebook, Twitter, and YouTube, with their GSM.

In a very unique effort to promote citizen-journalism in Nigeria, the BBC gave out free cell phones to its Hausa audience in the northern part of Nigeria to encourage them to contribute news items from their immediate environments to the broadcast corporation [14]. This approach by the BBC further gives credence to the outcome of the findings of this research that the Mobile Phone (GSM) is the leading technology for citizen-reporting in Nigeria. It also confirms that there is a need to support the Nigeria citizen-reporters with the needed tools so that they can fully take advantage of emerging technologies to report the news in their immediate environment.

\section{Networking During Protests}

When a 26 year old Tunisian fruit vendor out of frustration set himself on fire in a public square, the news was circulated by protesters with the Mobile Phone and it led to protests against dictators in Tunisia, Egypt and Libya. This incidence also rattled regimes in Syria, Yemen and Bahrain and spurred Mexicans against the terror of drug cartels, Greeks to march against unaccountable leaders, Americans to occupy public spaces to protest income inequality, and Russia against a corrupt autocracy [12]. Protesters stayed connected using their Cell phones as the protest progressed.

In United Kingdom, unemployed youths took to the streets in London and vandalized public places and property. The news of these protests was reported first by citizen-journalists on the Internet and social media and most of the reports were circulated using mobile phones.

On January 1, 2012, Nigerians treated the whole world to a display of social media tools and tactics as they flooded the information superhighways with stories of protests around the country against government withdrawal of fuel subsidy in the country. Then, ordinary citizens took to the streets armed with their Internet-ready camera phones to protest the government withdrawal of subsidy and report the protest to the local and international media. This development further confirms the findings in the research that GSM is a veritable tool in citizenreporting.

\section{SUMMARY}

The study is the first step in creating a foundational theoretical framework on how technology transforms the journalism business through citizen-reporters in Nigeria. A quotation that predicts the future of citizen-journalism, from the Media Center at the American Press Institute [7] that "media futurists have predicted that by 2021, citizens will produce 50 percent of the news peer-to-peer" was used to introduce the study. This position was further advanced in the literature review for study with Gillmor [5] which calls on traditional journalists to either wake up to the challenges posed by citizen-reports or be ready to be pushed to the background in the business of news reporting, gathering, or distribution.

After collecting data, performing analysis, and drawing conclusion, the previous prediction remains to be seen, but the result of this study points to the direction of the prediction (peer-to-peer news reporting). However, Gillmor's [5] observation runs parallel to the findings of this study because Nigerian citizen-reporters complement the traditional print journalists rather than throwing up any serious challenge that is capable of rendering the traditional print journalists irrelevant, as Gillmor would have the industry to believe. But the emergence of GSM as a leading tool for citizen-reporting in Nigeria is a great testimony to the ever-green nature of telephone technology as a technology of all time.

\section{RECOMMENDATIONS FOR FUTURE RESEARCH}

In the research, the impacts of technology (through citizen-reporters) were studied in relation to the print media in Nigeria. It is therefore suggested that future studies on the same topic approach the citizen-journalism phenomena in relation to television or radio. How lack of access to the Internet and emerging media technologies prevents Nigerians from embracing citizen-reporting is another gray area for future research.

Future researchers may also want to use other methods of inquiry to approach future study on the topic. The use of quantitative method is recommended to examine the extent to which technology has transformed the journalism business through citizen-reporting in Nigeria. This could potentially unveil how far that technology has transformed the journalism business in Nigeria.

Factors preventing Nigerians from embracing citizenreporting tools is equally worth looking into. This will help highlight the role of Internet bandwidth, power outages, and purchasing power in the use of media technologies for citizen-reporting in Nigeria.

The use of technology by Nigerian journalists is yet another area worth looking into by future researchers. This can be done in relation to print, radio, or television journalism in Nigeria to determine how far new technologies have helped the news delivery business in the country.

Since the focus of this study is Nigeria, the findings enumerated may not be generalizable in another country, due to different situations and approaches to the use of technology for citizen-reporting that may be found from country to country.

Being an initial theory building study (on citizen journalism in Nigeria), it will be necessary to conduct further research to test the generalization of the impacts of technology on the journalism business that emerged from this study. This could be achieved through a broad survey of the impacts of technology on journalism discussed in this study. Although the significance of these impacts was discussed by some of the participants in this study, further 
sample is needed to verify the perceived importance of each impact.

It is necessary to note that the themes synthesized in this study are a reflection of the impacts of technology on the journalism business in Nigeria discussed by participants in the study based on their lived experiences and not those deemed important by the researcher. The themes are rich in information and obviously need further examination and study.

Although the study unveils the poor quality of news reporting by citizen-reporters, further study is needed to determine the effectiveness of the new journalism.

\section{REFERENCES}

[1] Bock, T., \& Sergeant, J. (2002). Small sample market research. International Journal of Markey Research, 44(2), 235-244.

[2] Cooper, D., \& Schindler, P. (2008). Business research methods (10th ed.). New York, NY: McGraw-Hill Irwin.

[3] DeSanctis, G., \& Poole, M. S. (1994). Capturing the complexity in advanced technology use: Adaptive structuration theory. Organization Science, 5(2), 121-147. http://dx.doi.org/10.1287/orsc.5. $\underline{2.121}$

[4] Flew, T. (2008). New media: An introduction. Melbourne, Australia: Oxford University Press.

[5] Gillmor, D. (2004). We the media: Grassroots journalism by the people, for the people. Sebastopol, CA: O'Reilly.

[6] Griffin, A., \& Hauser, J. R. (1993). The voice of the customer. Marketing Science, 12(1), 1-27. http://dx.doi.org/10.1287/ mksc.12.1.1
[7] The Media Center at the American Press Institute. (n.d.). About we media. Retrieved January 19, 2012, from http://www.hypergene.net/wemedia/weblog.php

[8] Miles, M. B., \& Huberman, A. M. (1994). Qualitative data analysis (2nd ed.). Thousand Oaks, CA: Sage.

[9] Moretzsohn, S. (2006). Citizen journalism and the myth of redemptive technology. Brazilian Journalism Research, 2(2), 3146.

[10] Ong, W. (1982). Orality and Literacy: The technologizing of the word. London: Methuen. http://dx.doi.org/10.4324/978020332 $\underline{8064}$

[11] Papandrea, M. (2007). Citizen journalism and the reporter's privilege. Retrieved January 14, 2012, from http://lsr.nellco.org/bc $\underline{\operatorname{lsfp} / 16}$

[12] Stengel, R. (2011). Person of the Year. Time. Vol. 178, No 25.

[13] Stern, E.\& Gwathmey, E.(1994). Once Upon A Telephone: An Illustrated Social History. Harcourt Brace.

[14] Tangaza, J. (2009, September). Mobile phones link villages in Nigeria. Retrieved April 10, 2012, from: http://www.bbc.co.uk/worldservice/worldagenda/2009/09/090909 _worldagenda_hausa_mobiles.shtml

\section{AUTHOR}

Olubunmi Philip Aborisade, Ph.D. was with the State University of New York, USA. He is now with the College New Rochelle, New Rochelle, NY 10805 USA (email: oaborisade@cnr.edu or aborisade@hotmail.com).

Manuscript received May 20, 2012. Published as re-submitted by the author 7 August 2012. 